Vol. 1, Issue 2, pp. 148-152

\title{
E- LEARNING: A Scientific Approach in Education
}

\author{
Manish Ranjan Pandey ${ }^{2}$,Dr. Sohan Garg ${ }^{2}$ \\ 1. Research Scholar Singhania Univesity \\ 2. Professor, Department of MCA, RKGIT Ghaziabad (U.P.) INDIA -201003
}

\begin{abstract}
Introduction
Computers have become an integral part of our lives. The world is undergoing numerous transformations due to rapid development and diffusion of information and communication technologies in all walks of life. We have come to such a world where our pace of life slows down without the 'e'processes like e-mail, e-banking, e-booking, ecommerce, e-business etc. Now it is the time of e- learning. The development in computer technology has resulted in e-learning i.e. technology based distance learning programs conducted online wherein the students can communicate with peers and teachers. 'E- Learning refers to the use of Internet technologies to deliver a broad array of solutions that enhance knowledge and performance' (Rosenberg, 2001). Students heavily depend upon the computer to get tutorials, teachers sitting in front of the computer in their home or Call Centers and teaching multiple students at different locations and students receive constant feedback, news papers come with advertisement on online learning. The online learning has become an industry. Now pupils are getting the expertise of teachers in different parts of the world, they not only depend on their teachers in the classroom but also the teachers everywhere in the globe. This is the era of the rise of global learning community of students. Internet technologies have fundamentally altered the technical and economical landscape so radically that it is now possible to make quantum leaps in the use of technology for learning. Recognizing this, many universities worldwide started online learning programs (courses online), interaction with fellow students and teachers, and access to research libraries etc.
\end{abstract}

E-learning (electronic - learning) is internet enabled learning. It is an online learning or Web enabled learning. It is the application of Web-enabled technology for instruction and learning. It includes the use of educational resources, on the Web like online publications, online professional organizations, government/private sites, educational portals, links and bookmarks, classroom management tools and academic tools and resources, for the purpose of instruction and learning. What else it includes, Web enhanced instructions and Internet based communication (e mail, conferences, mailing list, chats, telephony and video conferences). Though computer is used for instruction and learning, the non-web technology does not come under e- learning. The entire computer based instructions like computer-assisted instruction, computer managed ${ }^{1}$ instruction, integrated learning systems, multimedia, interactive video, virtual reality, artificial intelligence etc. which are not delivered through the internet but still used for learning and instruction cannot be included in e-learning. However, these techniques when delivered via internet for instruction and learning, they become e-learning.

E-learning is based on four fundamental criteria: (1) E-learning is networked, which makes it capable of instant updating, storage/ retrieval, distribution and sharing of instruction and information. (2) It is delivered to the end user via a computer (also Web TV, cell phones, Pagers and Personal Digital Assistants) using standard Internet Technology such as the TCP/IP protocol and Web browsers that creates a universal delivery platform. (3) It focuses on the broadest view of learning, i. e. learning solutions that go beyond the traditional paradigms of training: it is not limited to the delivery of instruction but goes beyond training to include tools that improve performance. (4) E-learning spans distance. We can say that e-learning is a form of distance learning, but distance learning is not necessarily e- learning.

\section{Advantages of E- Learning}

E- Learning is web enabled and every one on the Web can receive virtually the same way. Yet the program can also be customized for different learning needs or different groups of people. People can access e-learning anywhere and any time. Moreover it cuts travel expenses, reduces the time it takes to train people and eliminates or significantly 


\section{Manish Ranjan Pandey, Dr. Sohan Garg / IOSR Journal of Engineering (IOSRJEN) www.iosrjen.org \\ ISSN : 2250-3021}

Vol. 1, Issue 2, pp. 148-152

reduces the need for a classroom/teacher infrastructure. Because it's web enabled, e-learning can be updated instantaneously, making the information more accurate and useful for a longer period of time. In e-learning, everyone gets the same content, presented in the same way. The web enables people to build enduring communities of practice where they can come together to share knowledge and insight long after a training pragramme ends. This can be a tremendous motivator for organizational learning. Further, e-learning solutions are highly scalable. Programmes can move from 10 participants to 100 or even 100,000 participants with little effort or incremental cost.

\section{How are the Educational Resources on the Web Helpful for E-Learning?}

Many Internet based resources can serve to facilitate classroom management tasks, assist with academic tasks, or provide support for instruction. Let us see one by one the broad categories of resourses available on the Web, useful for e learning.

Online Publications: Many educational journals now have an online version available via the Internet. Most of these on line publications include current and archived articles of interest to educators. E.g. http://www.thejournal.com

Online Professional Organizations: Most major professional organizations now have a web presence. Teacher's unions, professional associations, content area groups, technology groups, and many others have websites ranging from modest to robust in quality. Organizational websites typically provide calendars of events, archived papers, online stores and current news about issues critical to those institutions. e.g. http://www.iste.org

Government Sites: Government sites present critical and current educational resources. E.g. http://www.ed.gov/NLE

Educational Portals: Web sites, which include services such as search engine, news, e-mail, conferencing, electronic shopping, and chat rooms are called portals. A portal is a doorway to the Internet. e.g. http://www.nces.ed.gov, www.ehow.com www.click2learn.com

Links and Bookmarks: Some of the best online resources are discovered through hot links from one site to another. Websites often link to other sites similar the content of their own site. When you find a useful website, it is a very good idea to check its link page and explore related sites. e.g. http://www.nea.org

Classroom Management Tools: Classroom management tool in the web include downloadable or online tools that assist you in the tasks required for your classroom. Several sites offer software that creates online or paper tests and, if they are online, grade them for you and send you the results. These test generators can create tests by randomly selecting questions within their database of questions or you can select the questions to be included. Some of them allow you to add your own questions to the database. Many textbooks are adding these types of resources to their Web sites. Other Internet based management tools include formal and informal diagnostic tests to assess learning preferences, tools that generate class rolls with seating charts, and electronic grade books that let you store and easily average student grades. E.g. http://www.firn.edu/doe/doehome.htm

Academic Tools and Resources: Some of the most popular academic tools include worksheet generators of many types that help you make interesting student activity sheets. These tools help you to create content specific crossword puzzles, word searches, cryptograms, mathematical exercises, and multimedia flash cards.

One of the key academic resources available on the Internet is lesson plans. Some lesson plan sites offer subjectspecific plans; others offer lesson plans submitted by colleagues across nation. In addition to sites dedicated to lesson plans, links on many educational sites offer lesson plans related to the content of that site. A related lesson 


\title{
Manish Ranjan Pandey, Dr. Sohan Garg / IOSR Journal of Engineering (IOSRJEN) www.iosrjen.org

\author{
Vol. 1, Issue 2, pp. 148-152
}

plan resource is lesson plan software programs, which generate lesson plans for you and even relate them to specific standards. e.g. http://www.ed.gov/Technology/ http://www.ngfl.gov.uk

Reference tools and resources including dictionaries in all languages, thesauri, grammar and spelling tools, and word atlases are also available on the Internet. It also include translation references, specialty dictionaries and glossaries that relate to specific professions or hobbies and other vocabulary aids to provide you with a wealth of information about acronyms, anagrams and homonyms. Many of the most popular multimedia encyclopedias and research resources are available on the Internet. It is much useful for school media centers.

\section{How the Web-Enhanced Instruction is helpful for E-learning?}

An easy to use classroom website can enhance the learning environment. A classroom website can enhance teacherstudent, student-teacher and student-student communication in the classroom. For teacher student communication, a classroom website can contain daily, weekly or unit assignments and complete directions on how to complete them. It can also answer anticipated student questions on a 'frequently asked questions' page. It can contain information about grading or tips for working on an assignment. It can use web-based multimedia with voice, animation, or motion video to present key points in formats that address multiple learning preferences. This type of web page adds reinforcing dimensions to teacher-student communications.

E-learning can extend learning from school to home. An example of this is the use of the Internet observed in a Hong Kong primary school. The school's mathematics curriculum and exercises are stored on a website, which can be downloaded by students at home allowing them to complete homework and exercises and receive immediate feedback, as exercises are marked by the software program (Muijs, 2002).

Student-teacher communication can be enhanced via classroom website as well. Whether the student is in class but feels shy to voice his or her questions or the student is at home and struggling with an assignment, e-mail or teacherstudent electronics chat can provide an opportunity for direct, private and meaningful communication. Attending homework to an e-mail message can be a very effective tool that work is turned in on time. Electronic-conferencing can also support and enhance student-teacher communication, if the teacher moderates posted public questions activities or content.

For student-student communication, a website with e-mail or chat options or with electronic conferencing can encourage communication and build team work and communication skills. An activity in which students e-mail the draft of a written assignment to each other for editing before completing the final version provides an opportunity for students to exercise proof reading and grammar skills. A group project that requires participation in a chat or conference helps students develop communication skills while building technological skills. For shy students who would otherwise be reluctant to contribute verbally in class, this opportunity for thoughtful communication at a place that is comfortable for them may open new avenues of communication and build confidence in their own interaction skills. E.g. websites supporting classroom communication, http://www.connectedteacher.com http://www.teachlearning.com

We can utilize the classroom website as a communication tool to connect the classroom to others across the globe, there by building a global learning community for students. Key pals, e-pals, and cyber pals are some of the terms used to refer to the other people with whom students may correspond.

Building bridges with parents and community is another opportunity created through implementation of the Web in instruction. By posting classroom rules, schedules and home works on a class room web page, a teacher can directly communicate expectations to the parents of all students in a class. By adding communication tools including email, chat and conferencing, a means of private and public dialogue can be established. When you are seeking parent volunteers for classroom activities, posting such request on a classroom website makes more partnership and support possible. Help to inform parents in a timely manner about students' progress through classroom website. If you post 


\section{Manish Ranjan Pandey, Dr. Sohan Garg / IOSR Journal of Engineering (IOSRJEN) www.iosrjen.org \\ ISSN : 2250-3021}

Vol. 1, Issue 2, pp. 148-152

grades through websites parents can track how students are doing and even monitor their attendance. Such daily and weekly feedback to parents gives them a chance to join you in resolving performance issues. (Lever-Duffy, et.al, 2003)

\section{Live Classroom Training on the Web}

Much of the e-learning approaches are characterized as asynchronous. Asynchronous delivery refers to programmes that are independent of time (pre-recorded). Any one can access the programme at a time and as many times as desired. There is no live component, and in most cases nothing has to be scheduled. Communication between people does not take place in real time. Synchronous programmes on the other hand are time dependent. Communication takes place in the real time. The delivery is live, if you miss it, that's it. (Unless it is repeated again, or recorded, this would then make it asynchronous). Learning programmes on CD-ROMS are asynchronous, as are most web- based online training and knowledge management resources. The most obvious form of synchronous learning is classroom training or other forms of live group experiences, but some Web applications, such as chat rooms, are also synchronous.

If you put live classroom training on the Web, it is synchronous event. It is scheduled and parties (students and teachers) must be present at the time, just like any classroom event. But on the Web they don't have to be in the same place. Web technologies now allow synchronous learning at a distance.

There is a great deal of interest in Web based synchronous training and lots of products are in the market place. The main argument is that it will dramatically reduce travel costs and time. Several of these products offer combined synchronous and asynchronous features. The technology is not prohibitively expensive or unreasonably difficult to use. Isn't this a good way to utilize teachers in an e-learning environment? Isn't this a good foundation technology for your e-learning strategy?

\section{Use of Synchronous Delivery Technology in E-Learning}

1.Learning Management: Synchronous system can be used to coordinate and manage learning experiments, perhaps providing just enough structure to assure the learners 'show up' and continue participate. Short, scheduled live presentations, online chats, or other synchronous events can introduce subjects, and the teacher can assign work and set expectations. The synchronous class might resume with discussion and feedback regarding what was learned. E.g. http://www.unext.com, www.pensare.com www.universityaccess.com

2. Community Building: The technology can be used to reinforce communities of practice, especially between other learning events or after the formal training is over. Community meetings and special presentations can take place without people having leave their home or work sites. Threaded discussions, online chats, news groups, online conferencing, instant messaging, and personal web pages are some of the techniques that make the vital online community experience work.

3. Online Conferencing: Synchronous technology can help facilitate meetings by people who are separated by distance. The technology offers many enhancements over traditional conference calls, including the capability of combining voice, graphics, audio, live video, and the sharing of software applications. Indira Gandhi National Open University, Maidan Garhi, New Delhi (IGNOU) is well known Center in providing this type of learning experiences.

3. Rich media Delivery: The technology allows more media options to be delivered than it may be possible with just a browser. Through the use of specialized plug, full motion video and presentations slide can be synched to a speaker's voice to allow a presentation to be delivered as if it were live. Eloquent (www.elequent.com) is an example of a company that specializes in these services. 


\section{Manish Ranjan Pandey, Dr. Sohan Garg / IOSR Journal of Engineering (IOSRJEN) \\ www.iosrjen.org \\ ISSN : 2250-3021}

Vol. 1, Issue 2, pp. 148-152

4. Preservation: Key events and other unique situations can be recorded, then accessed and played back. This ability to archive actual events and make them available to any one, anywhere, and at any time is a boon to knowledge management.

If thought about this way, synchronous technology has a key role to play in e- learning strategy. We may fix 'distributed learning' - a mix of deliberately reduced face- to- face teaching and online learning as a safe e-learning strategy for secondary and tertiary education (Bates, 2001).

About 2000 students have successfully completed their education from Florida Online High School and the Code Consortium Virtual High School Started in this mode of e-learning. It has been estimated that there is about $90 \%$ growth in number of students who completed their education from such virtual high schools and universities of developed countries (Nambiar, 2006). Since primary school onwards the students are getting training to use the computer and internet and with so many millions (e.g. internet penetration across Europe is $40 \%$ of the population) of people already on the Web and comfortable with browser technology learning to access e-learning is quickly becoming a non-issue. In no time e-learning become widespread in schools and higher learning institutions as an effective and popular technology for teaching- learning. So India also has a bright future in providing the learning experience through electronics gadgets etc.

\section{$\underline{\text { References: }}$}

1. Bates, Tiny (2001). National Strategies for E-Learning in Post Secondary Education and Training. Paris: UNESCO.

2. Lever-Duffy, Judy, McDonald, Jean B. \& Mizell, Al P. (2003). Teaching and Learning with Technology. Boston: Allyn and Bacon.

3. Kumar. H (2002) A study of Neurological and Psycho social correlates of Scholastic backwardness, Ph. D Thesis ,J.M.I,New Delhi ,India

4. Muijs, Daniel \& Reynolds, David (2002). Effective Teaching: Evidence and Practice. London: Paul Chapman Publishing. A sage Publications Company.

5. Nambiar, Vijayan K K. (2005). Psychology of Learning and Instruction. Hyderabad, India: Neelkamal Publications Pvt.Ltd.

6. Rosenberg, Marc Jeffy (2001). E- Learning. New York: McGraw-Hill.

7. Stephenson, John (2001). Teaching \& Learning Online. London: Kogan Page. 